\title{
Cytotoxicity and Modes of Action of the Methanol Extracts of Six Cameroonian Medicinal Plants against Multidrug-Resistant Tumor Cells
}

\author{
Victor Kuete, ${ }^{1,2}$ Aimé G. Fankam, ${ }^{2}$ Benjamin Wiench, ${ }^{1}$ and Thomas Efferth ${ }^{1}$ \\ ${ }^{1}$ Department of Pharmaceutical Biology, Institute of Pharmacy and Biochemistry, Johannes Gutenberg University of Mainz, \\ Staudinger Weg 5, 55128 Mainz, Germany \\ ${ }^{2}$ Department of Biochemistry, Faculty of Science, University of Dschang, P.O. Box 67, Dschang, Cameroon
}

Correspondence should be addressed to Thomas Efferth; efferth@uni-mainz.de

Received 18 June 2013; Accepted 31 July 2013

Academic Editor: Shrikant Anant

Copyright (C) 2013 Victor Kuete et al. This is an open access article distributed under the Creative Commons Attribution License, which permits unrestricted use, distribution, and reproduction in any medium, provided the original work is properly cited.

Introduction. The present study aims at evaluating the cytotoxicity of twelve parts from six Cameroonian medicinal plants on sensitive and drug-resistant cancer cell lines. We also studied the mode of action of the most active plants, Gladiolus quartinianus, Vepris soyauxii, and Anonidium mannii. Methods. The cytotoxicity of the extracts was determined using a resazurin assay. Flow cytometry was used for cell-cycle analysis and detection of apoptosis, analysis of mitochondrial membrane potential (MMP), and measurement of reactive oxygen species (ROS). Results. At $40 \mathrm{~g} / \mathrm{mL}$, three extracts showed a growth of CCRF-CEM leukemia cells by less than $50 \%$. This includes the extracts from G. quartinianus (GQW; 25.69\%), Vepris soyauxii leaves (VSL; 29.82\%), and Anonidium mannii leaves (AML; 31.58\%). The lowest $\mathrm{IC}_{50}$ values below $30 \mu \mathrm{g} / \mathrm{mL}$ were obtained with GQW, AML and VSL against $7 / 9,8 / 9$, and $9 / 9$ tested cancer cell lines, respectively. The lowest $\mathrm{IC}_{50}$ values for each plant were $4.09 \mu \mathrm{g} / \mathrm{mL}$, and $9.14 \mu \mathrm{g} / \mathrm{mL}(\mathrm{against}$ U87MG. $\triangle E G F R$ cells), respectively, for VSL and AML and $10.57 \mu \mathrm{g} / \mathrm{mL}$ (against CCRF-CEM cells) for GQW. GQW induced cell cycle arrest between G0/G1 and S phases, whilst VSL and AML induced arrest in G0/G1. All three extracts induced apoptosis in CCRF-CEM cells by loss of MMP, whilst AML also enhanced production of ROS. Conclusion. The three active plants may be a source for the development of new anticancer drugs.

\section{Introduction}

Cancer is one of the major causes of death in humans representing the third leading cause of death worldwide (12.4\%), the first being cardiovascular disease (30\%) and the second being infectious diseases, including HIV/AIDS (18.8\%) [1]. Chemotherapy remains the treatment of choice in many malignant diseases [2]. Nevertheless, the appearance of drug resistance, in particular multidrug resistance (MDR), can make many of the clinically established anticancer drugs ineffective [3]. Thus, MDR is one of the major concerns preventing cure of many cancer patients. Also, malignancies are increasingly recognized as a critical public health problem in Africa [4]. Worldwide, the number of new cancer cases will annually reach 15 million by $2020,70 \%$ of which will occur in developing countries, where governments are less prepared to address the growing cancer burden and where survival rates are often less than half of those in more developed countries [4]. It has been observed that throughout the continent, though infectious diseases continue to burden African population, noninfectious diseases require much more attention [4]. Currently, limited funding is available to tackle cancer in African countries. Awareness of this impeding epidemic in Africa deserves priority, and further resources should be mobilized to both prevent and treat cancer. Research on anticancer agents has become a worldwide effort in both developed and developing countries, since chemotherapy is a mainstay in the treatment of many malignancies [5]. The majority of standard anticancer drugs has been isolated or derived from natural sources, based on their use in traditional medicine [6]. Screenings of medicinal plants used as anticancer drugs have provided modern medicine with effective cytotoxic pharmaceuticals. More than $60 \%$ of the approved anticancer drugs in USA were from natural origin [7-9]. 
In Cameroon, the use of plants in traditional medicine systems has been extensively documented in the Cameroonian pharmacopoeia [10]. Evidence highlighting the importance of these plants for cancer therapy has been provided [1116]. However, whether these plants are also effective in cells resistant to standard chemotherapy is largely unknown. It has been recommended that ethnopharmacological usages such as immune and skin disorders, inflammatory, infectious, parasitic, and viral diseases should be taken into account when selecting plants used to treat cancer, since these reflect disease states bearing relevance to cancer or cancerlike symptoms $[17,18]$. Though the plants selected in the present studied are used in the Cameroonian traditional medicine to fight cancers, there is still a lack of published data regarding the use. Therefore, in our continuous search of the cytotoxic candidates from Cameroonian plants with unpublished ethnopharmacological information related to cancer use, we investigated the antiproliferative potential of six Cameroonian plants against cancer cell lines with different mechanisms of drug resistance, that is, ATP-binding cassette (ABC) transporters (P-glycoprotein, breast cancer resistance protein), tumor suppressors (p53), or oncogenes (epidermal growth factor receptor). The most cytotoxic extracts from Gladiolus quartinianus A. Rich. (Iridaceae), Vepris soyauxii Engl. (Rutaceae) and Anonidium mannii (oliv) Engl. et Diels. (Annonaceae) were further analyzed to study their mode of action regarding cell-cycle distribution, MMP, and ROS.

\section{Materials and Methods}

2.1. Plant Material. All medicinal plants used in the present work were collected in different areas of Cameroon between January and April 2012 (Table 1). The plants were identified at the National Herbarium (Yaounde, Cameroon), where voucher, specimens were deposited under the references numbers given in Table 1 .

2.2. Extraction. The air-dried and powdered plant samples $(1 \mathrm{~kg})$ were soaked in methanol $(3 \mathrm{~L})$ for $48 \mathrm{~h}$, at room temperature. The methanol extracts were concentrated in vacuum to obtain the crude extracts [12]. These extracts were then stored at $4^{\circ} \mathrm{C}$ until further use.

2.3. Chemicals. Doxorubicin, vinblastine, and daunorubicin were provided by the University Pharmacy of the Johannes Gutenberg University (Mainz, Germany) and dissolved in PBS (Invitrogen, Eggenstein, Germany) at a concentration of $10 \mathrm{mM}$. Geneticin (72.18 mM) was purchased from SigmaAldrich (Munich, Germany).

2.4. Preliminary Phytochemical Investigations. The major secondary metabolites classes such as alkaloids, anthocyanins, anthraquinones, flavonoids, phenols, saponins, sterols, and triterpenes (Table 2) were determined according to a common phytochemical methods previously described [34].
2.5. Cell Cultures. Drug-sensitive CCRF-CEM and multidrug-resistant CEM/ADR5000 leukemia cells were maintained in RPMI 1640 medium (Invitrogen) supplemented with $10 \%$ fetal calf serum in a humidified $5 \% \mathrm{CO}_{2}$ atmosphere at $37^{\circ} \mathrm{C}$. Sensitive and resistant cells were kindly provided by Dr. Axel Sauerbrey (Department of Pediatrics, University of Jena, Jena, Germany). The generation of the resistant subline was described [35]. The specific overexpression of P-glycoprotein, but not other ABC transporters, has been reported [36, 37]. Breast cancer cells transduced with control vector (MDA-MB-231-pcDNA3) or with cDNA for the breast cancer resistance protein, $B C R P$ (MDA-MB-231- $B C R P$ clone 23) were maintained under standard conditions as described previously for CCRF-CEM cells. Human wild-type HCT116 $\left(p 53^{+/+}\right)$colon cancer cells as well as knockout clones HCT116 $\left(p 53^{-/-}\right)$derived by homologous recombination were a generous gift from Dr. B. Vogelstein and H. Hermeking (Howard Hughes Medical Institute, Baltimore, MD, USA). Human glioblastoma multiforme U87MG cells (nontransduced) and U87MG cell line transduced with an expression vector harboring an epidermal growth factor receptor (EGFR) gene with a genomic deletion of exons 2 through 7 (U87MG. $\triangle E G F R$ ) were kindly provided by Dr. W. K. Cavenee (Ludwig Institute for Cancer Research, San Diego, CA, USA) [38]. MDA-MB-231-BCRP, U87MG. $\triangle E G F R$, and HCT116 $\left(p 53^{-/-}\right)$were maintained in DMEM medium containing $10 \%$ FBS (Invitrogen) and $1 \%$ penicillin $(100 \mathrm{U} / \mathrm{mL})$ streptomycin $(100 \mu \mathrm{g} / \mathrm{mL})$ (Invitrogen) and were continuously treated with $800 \mathrm{ng} / \mathrm{mL}$ and $400 \mu \mathrm{g} / \mathrm{mL}$ geneticin, respectively. Human HepG2 hepatocellular carcinoma cells and normal AML12 hepatocytes were obtained from American Type Culture Collection (ATCC, USA). The previous medium without geneticin was used to maintain MDA-MB-231, U87MG, HCT116 $\left(p 53^{+/+}\right)$, HepG2, and AML12 cell lines. The cells were passaged twice weekly. All experiments were performed with cells in the logarithmic growth phase.

2.6. Resazurin Reduction Assay. Resazurin reduction assay $[16,39]$ was performed to assess cytotoxicity of the studied samples toward cancer cells. The assay is based on reduction of the indicator dye, resazurin, to the highly fluorescent resorufin by viable cells. Nonviable cells rapidly lose the metabolic capacity to reduce resazurin and thus produce no fluorescent signal. Briefly, adherent cells were detached by treatment with $0.25 \%$ trypsin/EDTA (Invitrogen, Darmstadt, Germany) and an aliquot of $1 \times 10^{4}$ cells was placed in each well of a 96-well cell culture plate (Thermo Scientific, Langenselbold, Germany) in a total volume of $200 \mu \mathrm{L}$. Cells were allowed to attach overnight and then were treated with different concentrations of the studied sample. For suspension cells, aliquots of $2 \times 10^{4}$ cells per well were seeded in 96-wellplates in a total volume of $100 \mu \mathrm{L}$. The studied sample was immediately added in varying concentrations in additional $100 \mu \mathrm{L}$ of culture medium to obtain a total volume of $200 \mu \mathrm{L} /$ well. After $24 \mathrm{~h}$ or $48 \mathrm{~h}, 20 \mu \mathrm{L}$ resazurin (SigmaAldrich, Schnelldorf, Germany) $0.01 \%$ w/v in $\mathrm{ddH}_{2} \mathrm{O}$ was added to each well and the plates were incubated at $37^{\circ} \mathrm{C}$ for $4 \mathrm{~h}$. Fluorescence was measured on an Infinite M2000 


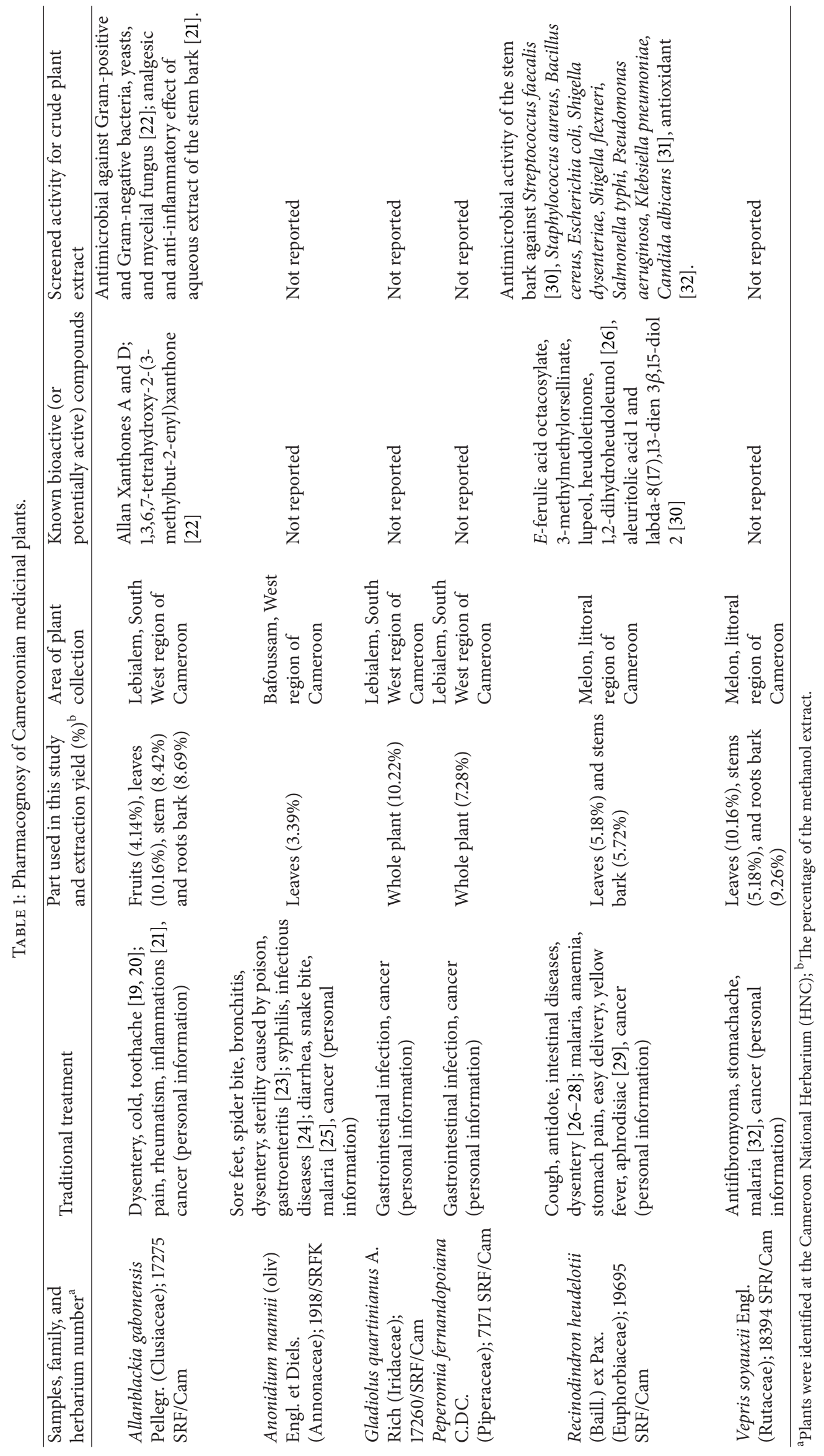


TABLE 2: Chemical constituents and extraction yield of the studied plant extracts.

\begin{tabular}{|c|c|c|c|c|c|c|c|c|c|}
\hline \multirow{2}{*}{ Studied samples } & \multicolumn{9}{|c|}{ Phytochemical constituents } \\
\hline & Alkaloids & Anthocyanins & Anthraquinones & Flavonoids & Phenols & Saponins & Tannins & Sterols & Triterpenes \\
\hline \multicolumn{10}{|c|}{ Allanblackia gabonensis } \\
\hline Leaves & + & + & - & + & + & - & + & - & - \\
\hline Stem bark & + & + & + & + & + & + & + & - & + \\
\hline Root bark & + & + & + & + & + & + & + & - & + \\
\hline Fruits & + & + & - & + & + & + & + & - & + \\
\hline \multicolumn{10}{|c|}{ Anonidium mannii } \\
\hline Leaves & + & - & - & - & + & + & + & + & + \\
\hline \multicolumn{10}{|c|}{ Gladiolus quartinianus } \\
\hline Whole plant & + & + & - & + & + & - & + & + & + \\
\hline \multicolumn{10}{|c|}{ Peperomia fernandopoiana } \\
\hline Whole plant & + & + & - & + & + & - & + & + & - \\
\hline \multicolumn{10}{|c|}{ Ricinodendron heudelotii } \\
\hline Leaves & + & - & - & - & + & + & + & - & + \\
\hline Stem bark & + & + & - & + & + & - & + & - & - \\
\hline \multicolumn{10}{|l|}{ Vepris soyauxii } \\
\hline Leaves & + & + & - & + & + & + & + & + & + \\
\hline Stem bark & + & + & + & + & + & + & + & - & + \\
\hline Roots bark & + & + & - & + & + & + & + & - & + \\
\hline
\end{tabular}

(+): present; (-): absent.

Pro plate reader (Tecan, Crailsheim, Germany) using an excitation wavelength of $544 \mathrm{~nm}$ and an emission wavelength of $590 \mathrm{~nm}$. Each assay was done at least two times, with six replicate each. The viability was evaluated based on a comparison with untreated cells. $\mathrm{IC}_{50}$ values represent the sample's concentrations required to inhibit $50 \%$ of cell proliferation and were calculated from a calibration curve by linear regression using Microsoft Excel.

2.7. Flow Cytometry for Cell Cycle Analysis and Detection of Apoptotic Cells. Cell-cycle analysis was performed by flow cytometry using The Vybrant DyeCycle (Initrogen). The Vybrant DyeCycle Violet stain is a DNA-selective, cell membrane-permeant, and nonfluorescent dye for DNA content analysis in living cells. The Vybrant DyeCycle Violet stain is fluorescent upon binding to double-stranded DNA. Leukemia CCRF-CEM cells $\left(1 \times 10^{6}\right)$ were treated with the concentrations equivalent to the $\mathrm{IC}_{50}$ values of the crude extract for $24 \mathrm{~h}, 48$, and $72 \mathrm{~h}$. Following incubation, $1 \mu \mathrm{L}$ of Vybrant DyeCycle Violet stain was added to $1 \mathrm{~mL}$ of cell suspension and incubated for $30 \mathrm{~min}$ at $37^{\circ} \mathrm{C}$. Cells were measured on an LSR-Fortessa FACS analyzer (BectonDickinson, Germany) using the violet laser. Ten thousand cells were counted for each sample. Vybrant DyeCycle Violet stain was measured with $440 \mathrm{~nm}$ excitation. Cytographs were analyzed using FlowJo software (Celeza, Switzerland). All experiments were performed at least in triplicate.

2.8. Analysis of Mitochondrial Membrane Potential (MMP). The effects of extract on the MMP were analyzed by $5,5^{\prime}, 6,6^{\prime}$ tetrachloro-1, $1^{\prime}, 3,3^{\prime}$-tetraethylbenzimidazolylcarbocyanine iodide) (JC-1; Biomol, Germany) staining. JC-1 is a dye that can selectively enter into mitochondria and exhibits an intense red fluorescence in healthy mitochondria with normal membrane potentials. In cells with reduced MMP, the red fluorescence disappears. Briefly, $1 \times 10^{6}$ CCRF-CEM cells treated with different concentrations of the test compounds or DMSO (solvent control) for $24 \mathrm{~h}$ were incubated with JC-1 staining solution according to the manufacturer's protocol for $30 \mathrm{~min}$. Subsequently, cells were measured in an LSR-Fortessa FACS analyzer (Becton-Dickinson). For each sample, $1 \times 10^{4}$ cells were counted. The JC-1 signal was measured with $561 \mathrm{~nm}$ excitation $(150 \mathrm{~mW})$ and detected using a 586/15 nm bandpass filter. The compounds signal was analyzed with $640 \mathrm{~nm}$ excitation $(40 \mathrm{~mW})$ and detected using a $730 / 45 \mathrm{~nm}$ bandpass filter. All parameters were plotted on a logarithmic scale. Cytographs were analyzed using FlowJo software (Celeza, Switzerland). All experiments were performed at least in triplicate.

2.9. Measurement of Reactive Oxygen Species (ROS) by Flow Cytometry. 2', $7^{\prime}$-Dichlorodihydrofluorescein diacetate ( $\left.\mathrm{H}_{2} \mathrm{DCFH}-\mathrm{DA}\right)$ (Sigma-Aldrich, Germany) is a probe used for the highly sensitive and quantifiable detection of ROS. The nonfluorescent $\mathrm{H}_{2}$ DCFH-DA diffuses into the cells and is cleaved by cytoplasmic esterases into $2^{\prime}, 7^{\prime}$ dichlorodihydrofluorescein $\left(\mathrm{H}_{2} \mathrm{DCF}\right)$ which is unable to diffuse back out of the cells. In the presence of hydrogen peroxide, $\mathrm{H}_{2} \mathrm{DCF}$ is oxidized to the fluorescent molecule dichlorofluorescein (DCF) by peroxidases. The fluorescent signal emanating from DCF can be measured and quantified by flow cytometry, thus providing an indication of intracellular ROS concentration [40, 41]. Briefly, $2 \times 10^{6}$ CCRFCEM cells were resuspended in PBS and incubated with 
$2 \mu \mathrm{M} \mathrm{H}_{2}$ DCFH-DA for 20 min in the dark. Subsequently, cells were washed with PBS and resuspended in RPMI 1640 culture medium containing different concentrations of extract or DMSO (solvent control). After $1 \mathrm{~h}$ of incubation, cells were washed and suspended in PBS. Subsequently, cells were measured in an FACS Calibur flow cytometer (Becton-Dickinson, Germany). For each sample $1 \times 10^{4}$ cells were counted. DCF was measured at $488 \mathrm{~nm}$ excitation $(25 \mathrm{~mW})$ and detected using a 530/30 nm bandpass filter. All parameters were plotted on a logarithmic scale. Cytographs were analyzed using FlowJo software (Celeza, Switzerland). All experiments were performed at least in triplicate.

\section{Results}

3.1. Chemical Composition of the Studied Extracts. The results of the qualitative analysis showed that each of the studied plant extract contained at least one class of secondary metabolites such as alkaloids, anthocyanins, anthraquinones, flavonoids, phenols, saponins, and triterpenes. All studied extracts contained alkaloids, phenols, and tannins (Table 2).

3.2. Cytotoxicity of the Studied Samples. The growth inhibition of CCRF-CEM cells induced by 12 extracts belonging to six medicinal plants is depicted in Figure 1. The extracts from Gladiolus quartinianus (whole plant; GQW; 25.69\%), Vepris soyauxii (leaves; VSL; 29.82\%), and Anonidium mannii (leaves; AML; $31.58 \%$ ) inhibited cell growth by more than $50 \%$ at $40 \mu \mathrm{g} / \mathrm{mL}$.

To investigate these extracts in more detail, their $\mathrm{IC}_{50}$ values were determined in a panel of cancer cell lines. The VSL extract was active $\left(\mathrm{IC}_{50}<40 \mu \mathrm{g} / \mathrm{mL}\right)$ against all 9 sensitive or drug-resistant cell lines. IC $_{50}$ values below $30 \mu \mathrm{g} / \mathrm{mL}$ were obtained with GQW, AML, and VSLagainst 7/9, 8/9, and 9/9 tested cancer cell lines, respectively. The $\mathrm{IC}_{50}$ values were in a range from $4.09 \mu \mathrm{g} / \mathrm{mL}$ (U87MG. $\triangle E G F R$ cells) to $13.60 \mu \mathrm{g} / \mathrm{mL}$ (HepG2 cells) for VSL from $10.57 \mu \mathrm{g} / \mathrm{mL}$ (CCRFCEM) to $34.01 \mu \mathrm{g} / \mathrm{mL}$ (U87MG. $\triangle E G F R$ ) for GQW, and from $9.14 \mu \mathrm{g} / \mathrm{mL}$ (U87MG. $\triangle E G F R$ ) to $32.02 \mu \mathrm{g} / \mathrm{mL}$ (MDA-MB231-BCRP) for AML. For the control drug doxorubicin, the $\mathrm{IC}_{50}$ values were in a range from $0.11 \mu \mathrm{g} / \mathrm{mL}$ (CCRFCEM cells) to $195.12 \mu \mathrm{g} / \mathrm{mL}$ (CEM/ADR5000 cells) (Table 3). High degrees of resistance to doxorubicin were observed for CEM/ADR 5000 cells (1772-fold), MDA-MB-231-BCRP cells (7.11-fold), and U87MG. $\triangle E G F R$ (5.76-fold) compared to their corresponding parental cell lines. HCT116 $\left(p 53^{-/-}\right)$cells were weakly resistant to doxorubicin (2.84-fold) compared to HCT116 $\left(p 53^{+/+}\right)$cells. Interestingly, the drug-resistant cell lines were not or only weakly resistant to the tested extracts ( $\leq 2.53$-fold). Remarkably, none of the tested extract inhibited the growth of more than 50\% normal AML12 hepatocytes at a concentration of $40 \mu \mathrm{g} / \mathrm{mL}$. Collateral sensitivity, which means that resistant cells are more sensitive than sensitive cells, was observed with the three extracts against U87MG. $\triangle E G F R$ with degree of resistances below 1 . This was also noted for the VSL and AML extracts against HepG2 cells and AML extract against CEM/ADR5000 cells. All the plant

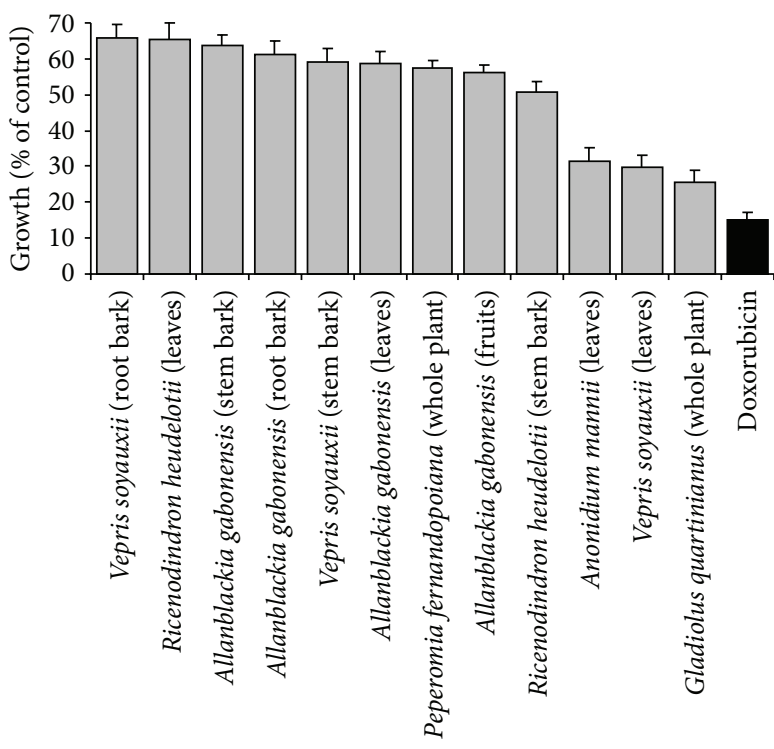

FIGURE 1: Growth (\% of untreated control) of CCRF-CEM leukemia cells in the presence of plant extracts $(40 \mu \mathrm{g} / \mathrm{mL})$ or doxorubicin $(10 \mu \mathrm{g} / \mathrm{mL})$.

extracts showed higher $\mathrm{IC}_{50}$ values in normal AML12 hepatocytes compared to HepG2 liver cancer cells. Furthermore, AML12 normal hepatocytes were more doxorubicin resistant than HepG2 cancer cells towards doxorubicin. None of the extracts inhibited normal AML12 hepatocytes by more than $50 \%$.

3.3. Cell Cycle Distribution and Apoptosis. The cell-cycle distribution and induction of apoptosis of CCRF-CEM cells upon treatment with GQW, VSL AML, are depicted in Figure 2. Upon $72 \mathrm{~h}$ treatment, the GQWextract induced cell cycle arrest between G0/G1 and S phases whilst VSL and AMLextracts induced G0/G1 arrest. The three extracts led to a time-dependent increase of sub-G0/G1 cells, indicating induction of apoptosis. CCRF-CEM cells treated with concentrations equivalent to the $\mathrm{IC}_{50}$ value of each studied extracts progressively underwent apoptosis, with percentages in sub-G0/G1 phase ranging from $11.2 \%(24 \mathrm{~h})$ to $44.3 \%$ (72 h) for GQW, from $19.7 \%(24 \mathrm{~h})$ to $53.2 \%(72 \mathrm{~h})$ for VSL, and from $22.7 \%(24 \mathrm{~h})$ to $76.2 \%(72 \mathrm{~h})$ for AML. The values of the sub-G0/G1 phase recorded with AMLwere higher than those obtained with nontreated cells (range from $3.82 \%(24 \mathrm{~h}$ ) to $9.37 \%(72 \mathrm{~h})$ ), but were comparable to those obtained for the control drug, doxorubicin (range from $59.4 \%(24 \mathrm{~h})$ to $71.9 \%(72 \mathrm{~h})$ ) (see Supplementary Material available online at http://dx.doi.org/10.1155/2013/285903, Figure S1).

3.4. Effect on the Mitochondrial Membrane Potential (MMP). We assessed the effect of the GQW, VSL, and AML extracts on MMP in CCRF-CEM cells. As shown in Figure 3, percentage alterations of $13.5 \%, 28.9 \%$, and $32.3 \%$ were induced by GQW, VSL, and AML extracts, respectively, after $24 \mathrm{~h}$ of treatment with twofold $\mathrm{IC}_{50}$. The MMP value for untreated cells was $4.81 \%$. Under similar experimental conditions, these values 
TABLE 3: Cytotoxicity of the studied extracts towards sensitive and drug-resistant cancer cell lines and normal cells as determined by the resazurin assay.

\begin{tabular}{lcccc}
\hline \multirow{2}{*}{ Cell lines } & \multicolumn{3}{c}{ Studied samples, $\mathrm{IC}_{50}$ values $(\mu \mathrm{g} / \mathrm{mL})^{\mathrm{a}}$ and degree of resistance (in bracket) } \\
& Gladiolus quartinianus $($ Whole plant) & Vepris soyauxii (Leaves) & Anonidium mannii (Leaves) & Doxorubicin \\
\hline CCRF-CEM & $10.57 \pm 2.08$ & $9.28 \pm 1.01$ & $17.32 \pm 2.27$ & $0.11 \pm 0.01$ \\
CEM/ADR5000 & $26.14 \pm 1.97(2.47)$ & $11.72 \pm 1.43(1.26)$ & $16.44 \pm 1.76(0.95)$ & $195.12 \pm 14.30(1772)$ \\
MDA-MB-231 & $16.11 \pm 1.62$ & $7.52 \pm 0.84$ & $12.65 \pm 1.49$ & $1.10 \pm 0.01$ \\
MDA-MB-231-BCRP & $29.6 \pm 3.19(1.49)$ & $12.93 \pm 1.69(1.71)$ & $32.02 \pm 3.16(2.53)$ & $7.83 \pm 0.01(7.11)$ \\
HCT116 p53 & $19.83 \pm 1.66$ & $8.59 \pm 0.88$ & $13.61 \pm 1.79$ & $1.43 \pm 0.02$ \\
HCT116 p53-/- & $22.15 \pm 1.97(1.12)$ & $9.70 \pm 0.72(1.12)$ & $*(>2.94)$ & $4.06 \pm 0.04(2.84)$ \\
U87MG & $*$ & $8.75 \pm 1.21$ & $22.25 \pm 2.76$ & $1.06 \pm 0.03$ \\
U87MG $\triangle E G F R$ & $34.01 \pm 2.78(<0.85)$ & $4.09 \pm 0.56(0.47)$ & $9.14 \pm 1.77(0.41)$ & $6.11 \pm 0.04(5.76)$ \\
HepG2 & $*$ (n.a) & $13.60 \pm 1.22(<0.34)$ & $22.09 \pm 2.42(0.55)$ & $1.41 \pm 0.12(<0.04)$ \\
AML12 & $*$ & $*$ & $*$ & $*$ \\
\hline
\end{tabular}

${ }^{\mathrm{a}}$ The degree of resistance was determined as the ratio of $\mathrm{IC}_{50}$ value of the resistant/IC $\mathrm{I}_{50}$ sensitive cell line.

(*): $>40 \mu \mathrm{g} / \mathrm{mL}$; n.a: not applicable.

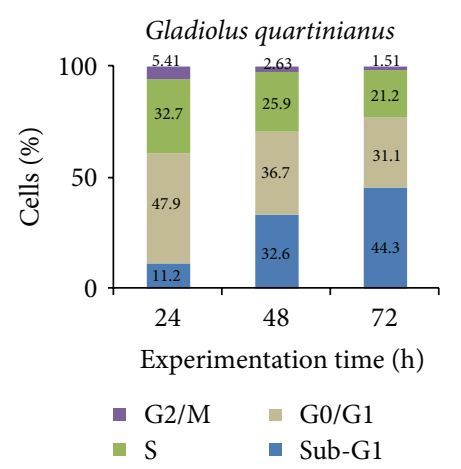

(a)

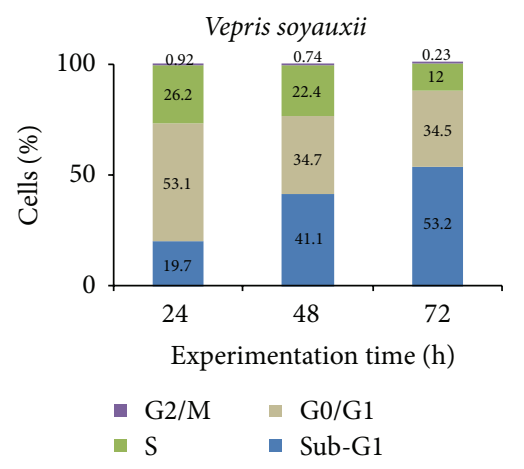

(b)

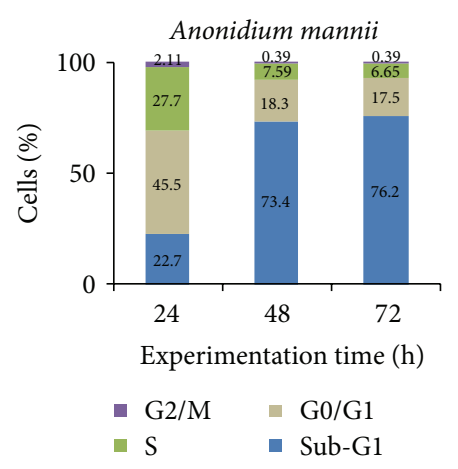

(c)

FIGURE 2: Cell-cycle distribution of CCRF-CEM cells treated with plant extractsordoxorubicin at their corresponding $\mathrm{IC}_{50}$ values for $72 \mathrm{~h}$. Data of control and doxorubicin obtained under similar experimental conditions were previously reported [33]. Flow cytometry histograms are available as supportive information (Figure S1).

were lower than that of the reference compound, vinblastine which yielded $48.6 \%$ as previously reported [33].

3.5. Effects on Reactive Oxygen Species (ROS). The effects of the GQW, VSL, and AMLextracts on ROS levels were investigated in CCRF-CEM cells after $24 \mathrm{~h}$ treatment (Figure 4). The control agent, $\mathrm{H}_{2} \mathrm{O}_{2}$, increased ROS level to $10.4 \%$, while ROS production in nontreated cells was $0.94 \%$. Only AML induced significant ROS production in CCRF-CEM cells treated with a concentration equivalent to $2 \times \mathrm{IC}_{50}(8.42 \%)$.

\section{Discussion}

Drug resistance is a complex multifactorial phenomenon that can result from a number of biochemical mechanisms, including decreased drug uptake or increased drug efflux, perturbed expression of target enzymes or altered target enzymes, altered metabolism of drugs, increased repair of drug-induced DNA damage, or failure to undergo apoptosis $[42,43]$. Resistance phenomena may lead to failure of therapy with fatal outcome for cancer patients. Secondary metabolites play an important role in plant defense against herbivores, microbial infections, and other interspecies defenses and can be exploited to fight human diseases, including cancer [44]. Their antiproliferative properties have been broadly discussed [45]. In the present study, the classes of secondary metabolites detected in the tested plant extracts (Table 2) provide a preliminary explanation on their activities. The obtained results represent the first phytochemical data on the cytotoxic activity of $G$. quartinianus, $V$. soyauxii, and $A$. manni.

According to the criteria of the ATCC, $30 \mu \mathrm{g} / \mathrm{mL}$ represent the upper $\mathrm{IC}_{50}$ limit considered promising for purification of a crude extract [46]. In the present work, the highest concentration tested $(40 \mu \mathrm{g} / \mathrm{mL})$ in our screening was slightly above this limit. Herein, we recorded $\mathrm{IC}_{50}$ values below $30 \mu \mathrm{g} / \mathrm{mL}$ for GQW, AML, and VSL extracts towards the majority of the tested cancer cell lines (Table 3 ). This demonstrates that the crude extracts of GQW, AML, and VSL could serve as potential sources of cytotoxic compounds. 

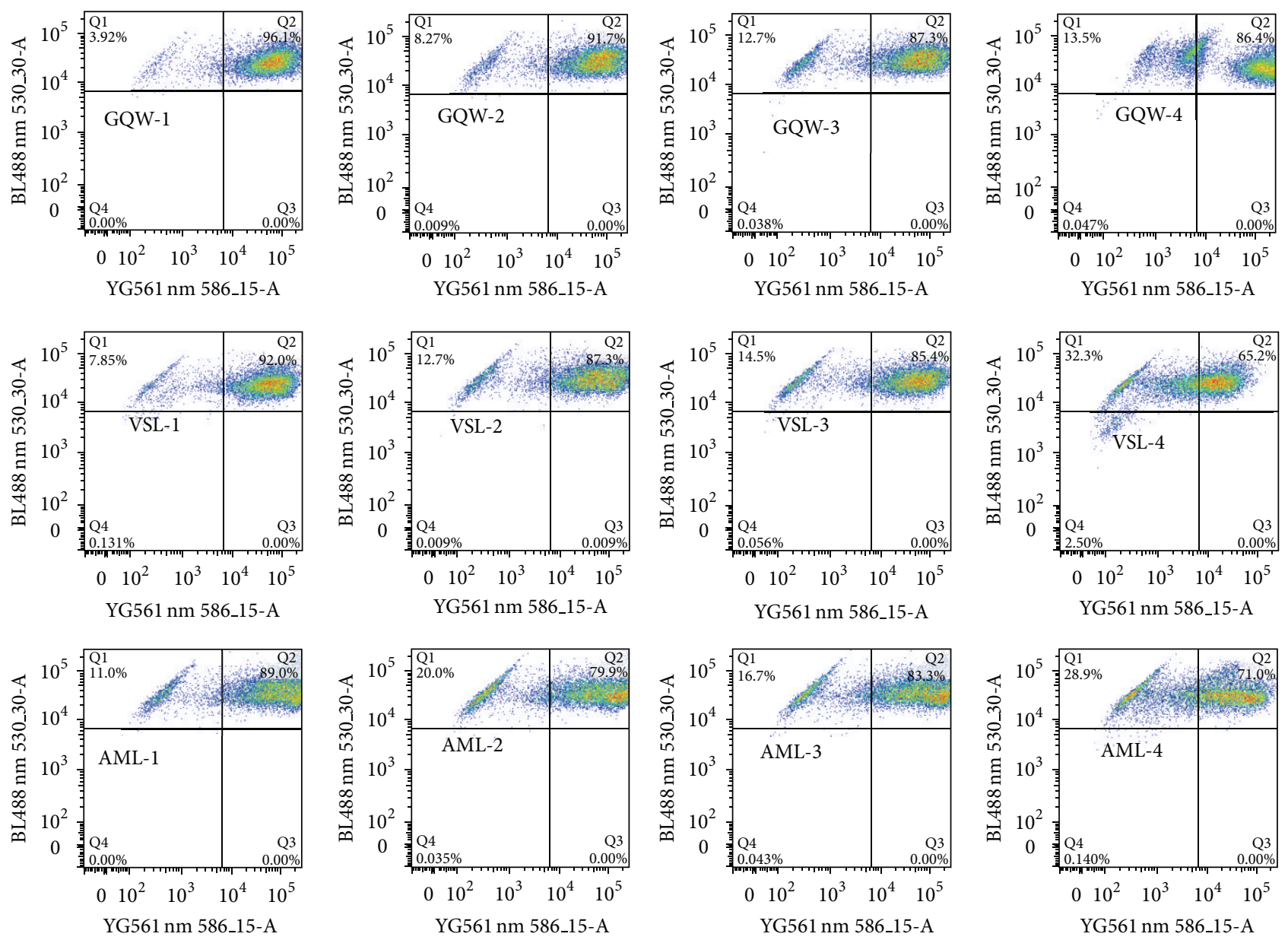

FIGURE 3: Effect of plant extracts and vinblastine (VIN) on the MMP of CCRF-CEM cells after $24 \mathrm{~h}$ of treatment. Data of control and vinblastine under similar experimental conditions were previously reported [33]. Samples were tested at their $1 / 4 \times \mathrm{IC}_{50}(1), 1 / 2 \times \mathrm{IC}_{50}(2)$, $\mathrm{IC}_{50}(3)$, and $2 \times \mathrm{IC}_{50}$ (4) values. The $\mathrm{IC}_{50}$ values are $0.20 \mu \mathrm{M}$ for VIN, $10.57 \mu \mathrm{g} / \mathrm{mL}$ (Gladiolus quartinianus whole plant, GQW), $9.28 \mu \mathrm{g} / \mathrm{mL}$ (Vepris soyauxii leaves, VSL), and $17.32 \mu \mathrm{g} / \mathrm{mL}$ (Anonidium mannii leaves, $A M L$ ).

In addition to the identification of crude extracts with reasonable low $\mathrm{IC}_{50}$ values, we identified extracts capable of killing otherwise drug-resistant cancer cells. Having in mind that drug resistance is a major obstacle of chemotherapy in the clinic, the search for novel noncross-resistant cytotoxic compound from natural sources is urgently warranted. Drug-resistant cell models overexpressing P-glycoprotein, BCRP, or $\triangle E G F R$ as well as p53 knockout cells were used to assess the suitability of the studied extracts to tackle multifactorial drug resistance. The degrees of resistance of the three extracts were generally lower than that of doxorubicin in corresponding drug-resistant cell lines (Table 3), clearly highlighting their possible role fighting multidrug resistance. It was pleasing that even collateral sensitivity was observed in several cases. This phenomenon is characterized by the fact that drug-resistant cells are more sensitive to a test compound than the parental sensitive cells [47, 48].

The objective of cancer chemotherapy is to kill cancer cells with as little damage as possible to normal cells [49].
The GQW, VSL, and AML extracts were more cytotoxic towards HepG2 liver carcinoma cells and the other cancer cell lines tested than towards normal AML12 hepatocytes. This highlights at least some specificity of the three plant extracts towards target malignant cells with little effects on normal cells.

We further found that the GQW, VSL, and AML extracts induced apoptosis by disruption of MMP, whilst in addition AML produced ROS. To the best of our knowledge, the cytotoxicity of GQW, VSL, and AML is being reported here for the first time. Therefore, the isolation of the active constituents from these plants is worthwhile for the better understanding of their activities towards cancer cells.

In conclusion, the present study provides evidence of the cytotoxic potential of GQW, VSL, and AML extracts on sensitive and drug-resistant cancer cell lines. The three extracts induced apoptosis in CCRF-CEM cells by loss of MMP and, in the case of AML, also enhanced ROS production. These plant extracts merit more detailed investigations to improve therapy of drug-resistant and refractory tumors in the future. 

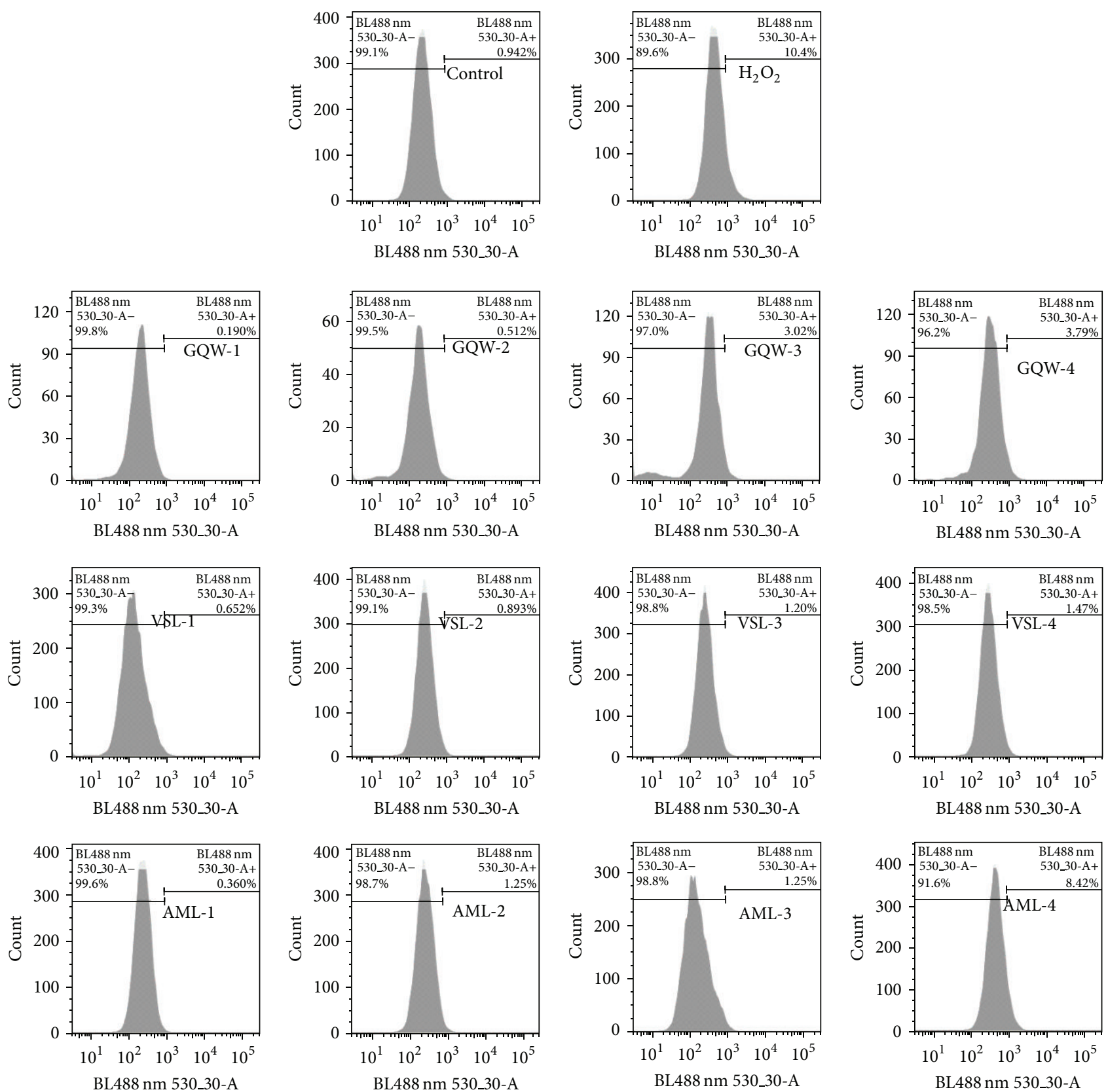

FIGURE 4: Effect of plant extracts and $\mathrm{H}_{2} \mathrm{O}_{2}$ (at $50 \mu \mathrm{M}$ ) on the ROS production of CCRF-CEM cells after $24 \mathrm{~h}$ treatment. Samples were tested at their $1 / 4 \times \mathrm{IC}_{50}(1), 1 / 2 \times \mathrm{IC}_{50}(2), \mathrm{IC}_{50}$ (3), and $2 \times \mathrm{IC}_{50}$ (4) values. The $\mathrm{IC}_{50}$ values are $10.57 \mu \mathrm{g} / \mathrm{mL}$ (Gladiolus quartinianus whole plant, $G Q W$ ), $9.28 \mu \mathrm{g} / \mathrm{mL}$ (Vepris soyauxii leaves, $V S L$ ), and $17.32 \mu \mathrm{g} / \mathrm{mL}$ (Anonidium mannii leaves, $A M L$ ).

\section{Conflict of Interests}

The authors declare that there is no conflict of interests regarding the publication of this paper.

\section{Authors' Contribution}

Victor Kuete, Aimé G. Fankam, and Benjamin Wiench carried out the experiments. Victor Kuete and Thomas Efferth designed the study. Victor Kuete wrote the paper. Thomas
Efferth supervised the work and provided the facilities for the study. All authors read and approved the final paper.

\section{Acknowledgment}

Victor Kuete is very grateful to the Alexander von Humboldt foundation for an 18 months' fellowship in Germany through the "Georg Foster Research Fellowship for Experienced Researcher" Program. 


\section{References}

[1] C. Mathers, C. Boschi-Pinto, A. Lopez, and C. Murray, Cancer Incidence, Mortality and Survival by Site for 14 Regions of the World, World Health Organization, Lyon, France, 2001.

[2] H. Lage, N. Duarte, C. Coburger, A. Hilgeroth, and M. J. U. Ferreira, "Antitumor activity of terpenoids against classical and atypical multidrug resistant cancer cells," Phytomedicine, vol. 17, no. 6, pp. 441-448, 2010.

[3] E. Borowski, M. M. Bontemps-Gracz, and A. Piwkowska, "Strategies for overcoming ABC-transporters-mediated multidrug resistance (MDR) of tumor cells," Acta Biochimica Polonica, vol. 52, no. 3, pp. 609-627, 2005.

[4] V. Kuete, "Recent advances in medicinal plant research in sub-saharan Africa," in Recent Progress in Medicinal Plants: Ethnomedicine and Therapeutic Validation, J. Govil and G. Kaushik, Eds., vol. 32, pp. 73-131, Studium Press, Houston, Tex, USA, 2012.

[5] S. Carter and R. Livingston, "Principle of cancer chemotherapy," in Principles of Cancer Treatment, S. Carter, E. Glatstein, and R. Livingston, Eds., pp. 95-110, McGraw-Hill, New York, NY, USA, 1982.

[6] M. Cragg and D. Newman, Natural Product Drugs Discovery in Next Millennium, National Cancer Institute, Frederick, Md, USA, 2001.

[7] C. Stévigny, C. Bailly, and J. Quetin-Leclercq, "Cytotoxic and antitumor potentialities of aporphinoid alkaloids," Current Medicinal Chemistry-Anti-Cancer Agents, vol. 5, no. 2, pp. 173182, 2005.

[8] D. J. Newman and G. M. Cragg, "Natural products as sources of new drugs over the last 25 years," Journal of Natural Products, vol. 70, no. 3, pp. 461-477, 2007.

[9] D. J. Newman and G. M. Cragg, "Natural products as sources of new drugs over the 30 years from 1981 to 2010," Journal of Natural Products, vol. 75, no. 3, pp. 311-335, 2012.

[10] J. Adjanohoun, N. Aboubakar, K. Dramane et al., Traditional Medicine and Pharmacopoeia: Contribution to Ethnobotanical and Floristic Studies in Cameroon, OUA/STRC, Lagos, Nigeria, 1996.

[11] V. Kuete, A. T. Mbaveng, M. Tsaffack et al., "Antitumor, antioxidant and antimicrobial activities of Bersama engleriana (Melianthaceae)," Journal of Ethnopharmacology, vol. 115, no. 3, pp. 494-501, 2007.

[12] V. Kuete, B. Krusche, M. Youns et al., "Cytotoxicity of some Cameroonian spices and selected medicinal plant extracts," Journal of Ethnopharmacology, vol. 134, no. 3, pp. 803-812, 2011.

[13] J. P. Dzoyem, A. H. L. N. Kuete, V. Kuete et al., "Cytotoxicity and antimicrobial activity of the methanol extract and compounds from Polygonum limbatum," Planta Medica, vol. 78, no. 8, pp. 787-792, 2012.

[14] A. T. Choumessi, M. Danel, S. Chassaing et al., "Characterization of the antiproliferative activity of Xylopia aethiopica," Cell Division, vol. 7, article 8, 2012.

[15] J. Dzoyem, S. Guru, C. Pieme et al., "Cytotoxic and antimicrobial activity of selected Cameroonian edible plants," $B M C$ Complementary and Alternative Medicine, vol. 13, article 78, 2013.

[16] J. D. Tamokou, J. Chouna, E. Fischer-Fodor et al., "Anticancer and antimicrobial activities of some antioxidant-rich cameroonian medicinal plants," PLoS ONE, vol. 8, no. 2, Article ID e55880, 2013.
[17] G. A. Cordell, C. W. W. Beecher, and J. M. Pezzuto, "Can ethnopharmacology contribute to the development of new anticancer drugs?" Journal of Ethnopharmacology, vol. 32, no. 1-3, pp. 117-133, 1991.

[18] J. Popoca, A. Aguilar, D. Alonso, and M. L. Villarreal, “Cytotoxic activity of selected plants used as antitumorals in Mexican traditional medicine," Journal of Ethnopharmacology, vol. 59, no. 3, pp. 173-177, 1998.

[19] A. Raponda-Walker and R. Sillans, Les plantes utiles du Gabon, Paul Lechevalier, Paris, France, 1976.

[20] J. Vivien and J. Faure, Fruitiers sauvages d'Afrique: especes du Cameroun, Coopération Française, Paris, France, 1995.

[21] E. V. Ymele, A. B. Dongmo, and T. Dimo, "Analgesic and antiinflammatory effect of aqueous extract of the stem bark of Allanblackia gabonensis (Guttiferae)," Inflammopharmacology, vol. 21, no. 1, pp. 21-30, 2013.

[22] A. G. B. Azebaze, B. M. W. Ouahouo, J. C. Vardamides et al., "Antimicrobial and antileishmanial xanthones from the stem bark of Allanblackia gabonensis (Guttiferae)," Natural Product Research, vol. 22, no. 4, pp. 333-341, 2008.

[23] J. Thomas, S. Bahuchets, A. Epelboin, and S. Furniss, Encyclopédie des Pygmées Aka: techniques, langage et société des chasseurs-cueilleurs de la forêt centrafricaine (Sud-Centrafrique et Nord-Congo), Peeters-SELAF, Paris, France, 2003.

[24] E. Noumi and M. Eloumou, "Syphilis ailment: prevalence and herbal remedies in Ebolowa subdivision (South region, Cameroon)," International Journal of Biomedical and Pharmaceutical Sciences, vol. 2, no. 1, pp. 20-28, 2011.

[25] J. Betti, "An ethnobotanical study of medicinal plants among the Baka Pygmies in the Dja Biosphere Reserve, Cameroon," African Study Monographs, vol. 25, pp. 1-27, 2004.

[26] S. F. Kimbu, F. Keumedjio, L. B. Sondengam, and J. D. Connolly, "Two dinorditerpenoids from Ricinodendron heudelotii," Phytochemistry, vol. 30, no. 2, pp. 619-622, 1991.

[27] E. Noumi and A. Yomi, "Medicinal plants used for intestinal diseases in Mbalmayo Region, Central Province, Cameroon," Fitoterapia, vol. 72, no. 3, pp. 246-254, 2001.

[28] J. Momeni, M. Akam, S. Kimbu, and W. Kreiser, "Diterpenoids from Ricinodendron heudelotii (Euphorbiaceae)," Journal of the Cameroon Academy of Science, vol. 6, no. 1, pp. 119-124, 2006.

[29] J. Fondoun, T. Tiki, and J. Kengue, "Recinodindron heudelotii (Djansang): ethnobotany and importance for forest dwellers in Southern Cameroon," Plant Genetic Resources Newsletter, vol. 118, pp. 1-6, 1999.

[30] J. Momeni, R. D. Djoulde, M. T. Akam, and S. F. Kimbu, "Chemical constituents and antibacterial activities of the stem bark extracts of Ricinodendron heudelotii (Euphorbiaceae)," Indian Journal of Pharmaceutical Sciences, vol. 67, no. 3, pp. 386389, 2005.

[31] E. Tekwu, A. Pieme, and V. Beng, "Investigations of antimicrobial activity of some Cameroonian medicinal plant extracts against bacteria and yeast with gastrointestinal relevance," Journal of Ethnopharmacology, vol. 142, no. 1, pp. 265-273, 2012.

[32] J. Momeni, W. P. D. D. Ntchatchoua, F. Fadimatou, M. T. Akam, and M. B. Ngassoum, "Antioxidant activities of some cameroonian plants extracts used in the treatment of intestinal and infectious diseases," Indian Journal of Pharmaceutical Sciences, vol. 72, no. 1, pp. 140-144, 2010.

[33] V. Kuete, P. D. Tchakam, B. Wiench et al., "Cytotoxicity and modes of action of four naturally occuring benzophenones: 2,2',5,6' -tetrahydroxybenzophenone, guttiferone E, isogarcinol 
and isoxanthochymol," Phytomedicine, vol. 20, no. 6, pp. 528536, 2013.

[34] J. Harbone, Phytochemical Methods: A Guide to Modern Techniques of Plant Analysis, Chapman \& Hall, London, UK, 1973.

[35] A. Kimmig, V. Gekeler, M. Neumann et al., "Susceptibility of multidrug-resistant human leukemia cell lines to human interleukin 2-activated killer-cells," Cancer Research, vol. 50, no. 21, pp. 6793-6799, 1990.

[36] T. Efferth, A. Sauerbrey, A. Olbrich et al., "Molecular modes of action of artesunate in tumor cell lines," Molecular Pharmacology, vol. 64, no. 2, pp. 382-394, 2003.

[37] J. Gillet, T. Efferth, D. Steinbach et al., "Microarray-based detection of multidrug resistance in human tumor cells by expression profiling of ATP-binding cassette transporter genes," Cancer Research, vol. 64, no. 24, pp. 8987-8993, 2004.

[38] H. S. Huang, M. Nagane, C. K. Klingbeil et al., “The enhanced tumorigenic activity of a mutant epidermal growth factor receptor common in human cancers is mediated by threshold levels of constitutive tyrosine phosphorylation and unattenuated signaling," The Journal of Biological Chemistry, vol. 272, no. 5, pp. 2927-2935, 1997.

[39] J. O'Brien, I. Wilson, T. Orton, and F. Pognan, “Investigation of the Alamar Blue (resazurin) fluorescent dye for the assessment of mammalian cell cytotoxicity," European Journal of Biochemistry, vol. 267, no. 17, pp. 5421-5426, 2000.

[40] D. A. Bass, J. W. Parce, and L. R. Dechatelet, "Flow cytometric studies of oxidative product formation by neutrophils: a graded response to membrane stimulation," Journal of Immunology, vol. 130, no. 4, pp. 1910-1917, 1983.

[41] A. Cossarizza, R. Ferraresi, L. Troiano et al., "Simultaneous analysis of reactive oxygen species and reduced glutathione content in living cells by polychromatic flow cytometry," Nature Protocols, vol. 4, no. 12, pp. 1790-1797, 2009.

[42] E. Teodori, S. Dei, C. Martelli, S. Scapecchi, and F. Gualtieri, "The functions and structure of ABC transporters: implications for the design of new inhibitors of Pgp and MRP1 to control multidrug resistance (MDR)," Current Drug Targets, vol. 7, no. 7, pp. 893-909, 2006.

[43] G. Szakács, J. K. Paterson, J. A. Ludwig, C. Booth-Genthe, and M. M. Gottesman, "Targeting multidrug resistance in cancer," Nature Reviews Drug Discovery, vol. 5, no. 3, pp. 219-234, 2006.

[44] N. Stamp, "Out of the quagmire of plant defense hypotheses," Quarterly Review of Biology, vol. 78, no. 1, pp. 23-55, 2003.

[45] V. Kuete and T. Efferth, "Pharmacogenomics of Cameroonian traditional herbal medicine for cancer therapy," Journal of Ethnopharmacology, vol. 137, no. 1, pp. 752-766, 2011.

[46] M. Suffness and J. Pezzuto, "Assays related to cancer drug discovery," in Methods in Plant Biochemistry: Assays for Bioactivity, K. Hostettmann, Ed., pp. 71-133, Academic Press, London, UK, 1990.

[47] K. M. Pluchino, M. D. Hall, A. S. Goldsborough, R. Callaghan, and M. M. Gottesman, "Collateral sensitivity as a strategy against cancer multidrug resistance," Drug Resistance Updates, vol. 15, no. 1-2, pp. 98-105, 2012.

[48] M. Saeed, H. Greten, and T. Efferth, "Molecular mechanisms of tumor cell resistance to chemotherapy," in Collateral Sensitivity in Drug-Resistant Tumor Cells, B. Bonavida, Ed., pp. 187-211, Springer, New York, NY, USA, 2013.

[49] B. Halliwell and J. Gutteridge, Free Radicals in Biology and Medicine, Charendon Press, Oxford, UK, 2nd edition, 1988. 


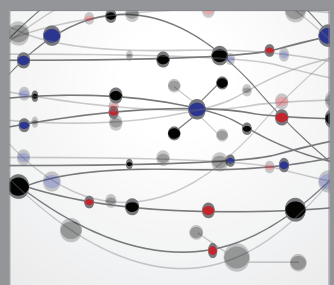

The Scientific World Journal
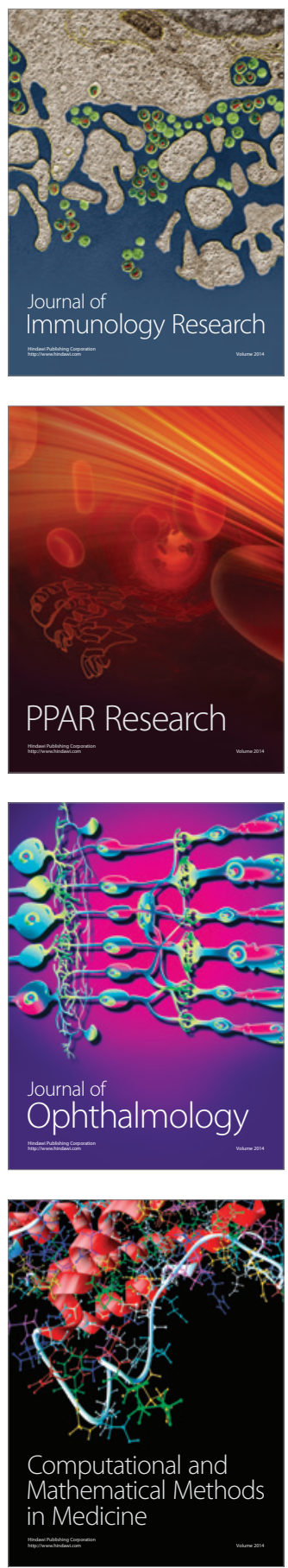

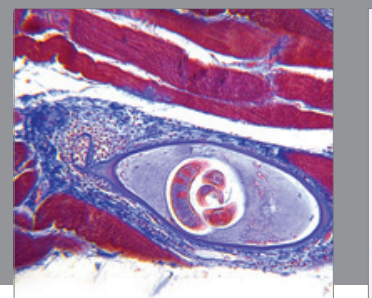

Gastroenterology

Research and Practice
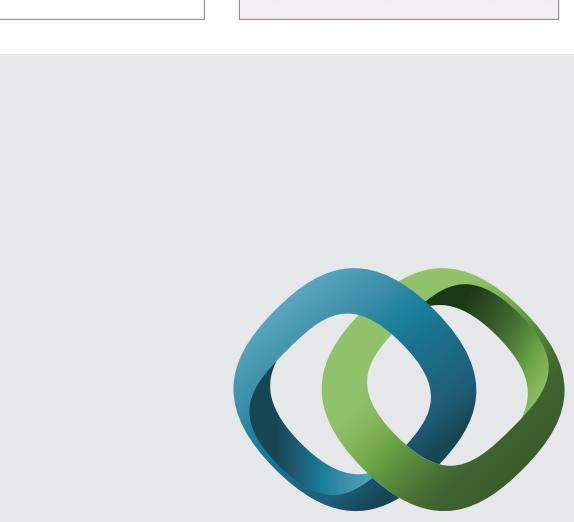

\section{Hindawi}

Submit your manuscripts at

http://www.hindawi.com
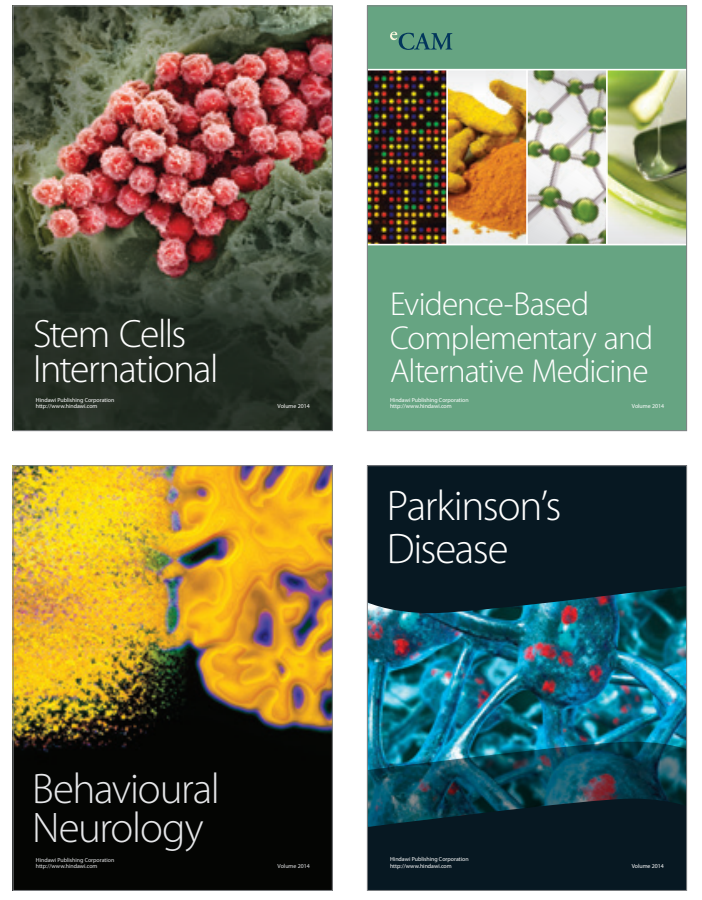
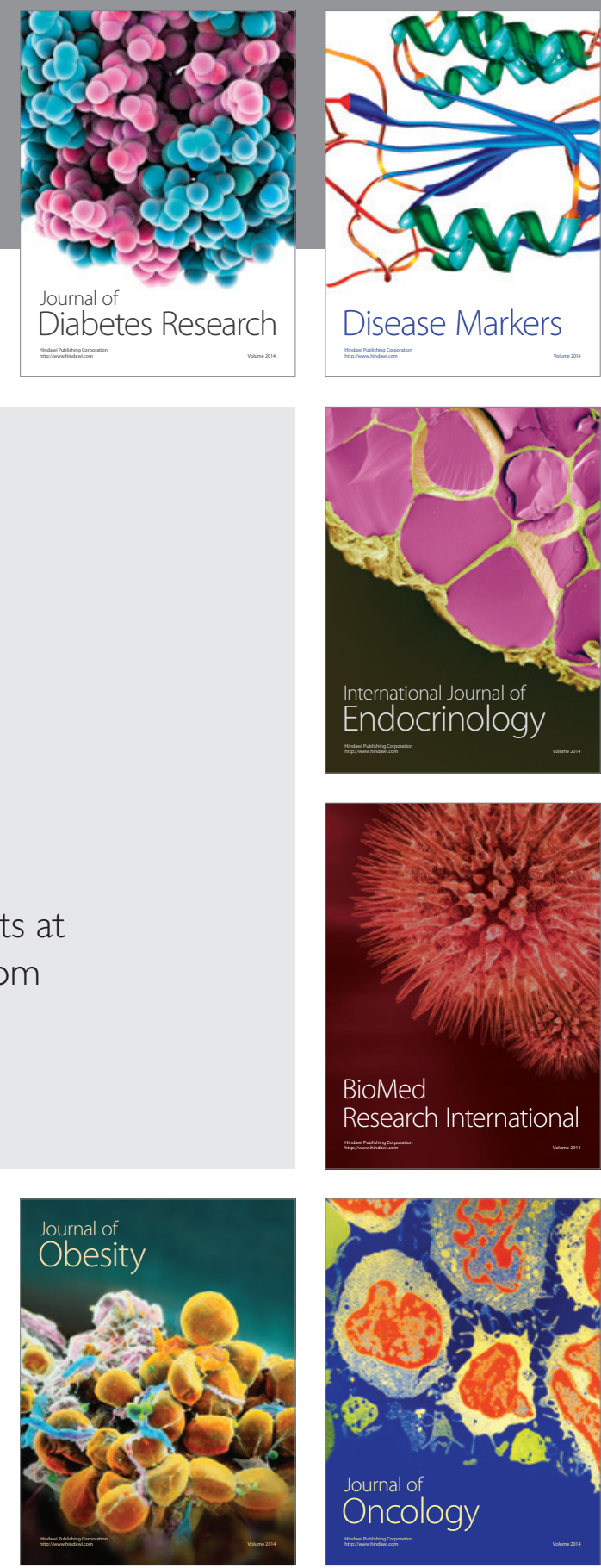

Disease Markers
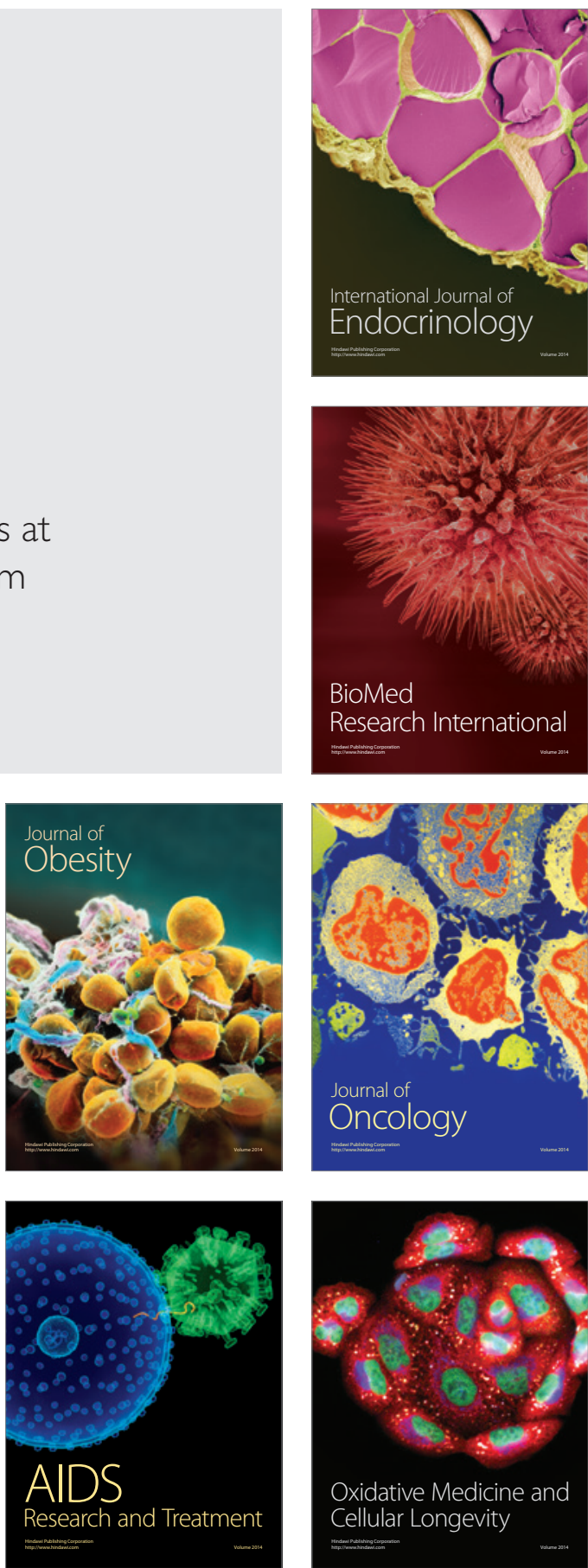